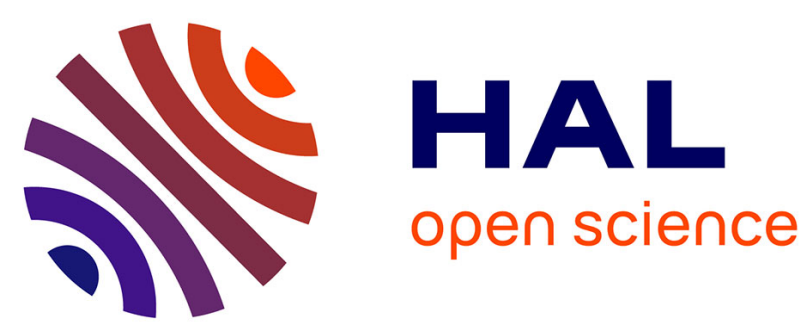

\title{
Use of green roofs to solve storm water issues at the basin scale - Study in the Hauts-de-Seine County (France)
}

Pierre-Antoine Versini, Pascal Jouve, David Ramier, Emmanuel Berthier, Bernard de Gouvello

\section{To cite this version:}

Pierre-Antoine Versini, Pascal Jouve, David Ramier, Emmanuel Berthier, Bernard de Gouvello. Use of green roofs to solve storm water issues at the basin scale - Study in the Hauts-de-Seine County (France). Urban Water Journal, 2015, pp.25. 10.1080/1573062X.2014.993993 . hal-01151786

\author{
HAL Id: hal-01151786 \\ https://hal.science/hal-01151786
}

Submitted on 17 May 2015

HAL is a multi-disciplinary open access archive for the deposit and dissemination of scientific research documents, whether they are published or not. The documents may come from teaching and research institutions in France or abroad, or from public or private research centers.
L'archive ouverte pluridisciplinaire HAL, est destinée au dépôt et à la diffusion de documents scientifiques de niveau recherche, publiés ou non, émanant des établissements d'enseignement et de recherche français ou étrangers, des laboratoires publics ou privés. 
1 Use of green roofs to solve storm water issues at the basin scale -

2 Study in the Hauts-de-Seine County (France)

3

4 Pierre-Antoine Versini ${ }^{1, *}$, Pascal Jouve ${ }^{2}$, David Ramier ${ }^{3}$, Emmanuel

5 Berthier $^{3}$, Bernard de Gouvello ${ }^{1}$

6

$7 \quad{ }^{1}$ Centre Scientifique et Technique du Bâtiment (CSTB) et Laboratoire Eau

8 Environnement et Systèmes Urbains (LEESU), 6-8 avenue Blaise Pascal 77455

9 Marne-la-Vallée, France

${ }^{2}$ Conseil Général des Hauts-de-Seine, Direction de l'Eau, 61 rue Salvador Allende, 92751 Nanterre, France

${ }^{3}$ Centre d'études et d'expertise sur les risques, l'environnement, la mobilité et l'aménagement (Cerema), DTer IDF, 12 rue Teisserenc de Bort, 78190 Trappes-en-

* Corresponding author: pierre-antoine.versini@leesu.enpc.fr 
1 Use of green roofs to solve storm water issues at the basin scale -

2 Study in the Hauts-de-Seine county (France)

3

4

5

6

7

8

9

At the building scale, green roof has demonstrated a positive impact on urban runoff (decrease in the peak discharge and runoff volume). This work aims to study if similar impacts can be observed at basin scale. It is particularly focused on the possibility to solve some operational issues caused by storm water.

For this purpose, a methodology has been proposed. It combines: a method to estimate the maximum roof area that can be covered by green roof, called green roofing potential, and an urban rainfall-runoff model able to simulate the hydrological behaviour of green roof.

This methodology was applied to two urban catchments affected one by flooding and the other one by combined sewage overflow. The results show that green roof can reduce the frequency and the magnitude of such problems depending on the covered roof surface. Combined with other infrastructures, they represent an interesting solution for urban water management.

Keywords: Flooding, green roof, hydrological modelling, scale study, sewage network, SWMM 


\section{Introduction}

The increase in impervious surfaces typically associated with urban development is responsible for numerous water management issues both within and outside cities. Storm water runoff affects water quantity and quality causing urban flooding and overflows. It is especially the case in combined sewer systems where urban pollution represents an important issue. Many techniques have been developed (storm water ponds, retention basin, open channels, infiltration systems...) to address these problems and limit the saturation of the storm water sewage network (Ferguson, 1998; White, 2002, Campisano et al., 2011). Usually, these infrastructures aim to temporarily store excess water before sending it slowly back into the network or the environment (by the mean of discharge, infiltration, or evaporation).

Nevertheless, these infrastructures require available land spaces that are more scarce in densely built downtown urban areas. To cope with urbanization and the problem of space, storm water source control (SC) has gained relevance over traditional sewer approaches (Delleur, 2003; Urbonas and Jones, 2001; Chouli, 2006; Petrucci et al., 2012). The principle of SC is to develop at small-scale (about $10^{2}-10^{3} \mathrm{~m}^{2}$ ), simultaneously to urban growth, facilities to prevent storm water problems at intermediate scales $\left(10^{4}-10^{6} \mathrm{~m}^{2}\right)$. These techniques include green roofs, porous pavements or harvesting tanks, for instance.

Green roofs appear to be particularly relevant because roof areas represent a significant part of the impervious surfaces in urban areas (between 40 and 50\%, Villarreal and Bengtsson, 2005). At the building scale, the main performance of green roofs in quantitative management of storm water is known to be the reduction of runoff volume at the annual scale and the peak attenuation and delay at the rainfall event scale depending on the green roof structure, the rainfall intensity and the antecedent soil moisture conditions (see Palla et al., 2009; VanWoert et al., 2005; Jarret et al., 2006 for detailed studies). Moreover, green roofs can avoid the direct contribution of toxic metals as those produced by zinc or lead roof 
1 (Egodawatta et al., 2009; Gromaire et al., 2011). For these reasons, over recent years the

spread of green roofs is currently underway in developed countries, and more and more green roofs are established. The annual growth in green roof covering is estimated to be between 0.1 to $1 \mathrm{~km}^{2}$ in several countries all over the world (Spain, Brazil, Canada, Korea, UK or Japan), while it is estimated to reach $2 \mathrm{~km}^{2}$ in France and higher than $10 \mathrm{~km}^{2}$ in Germany (Lassalle, 2012).

Despite the current spread of green roofs, few works have been published on their impacts on stormwater runoff to solve urban management issues. To our knowledge, most of the previous quoted studies have been focused on the hydrological impact of green roof at the building scale where these impacts initially occur. These works usually present the results provided by an experimental green roof instrumented to collect continuous runoff and precipitation data over short periods of time (not exceeding 3 years): see Bengtsson, 2005; Palla et al., 2008a; Voyde et al., 2010; Gregoire and Clausen, 2011; Stovin et al., 2012 for instance. In some cases, a rainfall-runoff model has especially been developed to simulate the green roof response (Hilten et al., 2008; Palla et al., 2009; Berthier et al., 2011). In these cases, the observations provided on the experimental set up are used to calibrate the model. Finally, very few studies assessed the possible impacts of green roof at larger catchment scale (Mentens et al., 2003; Carter and Jackson, 2007; Palla et al., 2008b), and even less to directly test the implementation of green roof to improve storm water management.

Based on these considerations, this paper aims to study how the spatial distribution of green roofs throughout the watershed can reduce the total volume entering into the drainage network. It is particularly focussed on how far the implementation of green roofs at large scale may impact urban runoff and can eventually solve some operational issues.

This work has been conducted on real cases where the current configuration of the sewage network causes risk situations. A methodology has been proposed to assess the green roof 
1 impact at the urban scale. It has been applied on two urban basins affected by flooding and

2 Combined Sewage Overflows (CSO) that are presented in Section 2. The methodology is developed in Section 3. It combines a method of defining green roofing scenarios which estimate the maximum roof area that can be covered, the green roofing potential and a modelling tool able to simulate the hydrological behaviour of green roofs. Integrated into an urban rainfall-runoff model, this tool has been used to study the consequences of several green roofing scenarios in terms of discharge and CSO reduction (Section 4). Finally, the results are synthesized and discussed in Section 5.

\section{Presentation of the Case study (the Hauts-de-Seine county)}

The Hauts-de-Seine County is located west of Paris (France). It is a highly populated and urbanized area (1.5 million inhabitants for a surface of $\left.176 \mathrm{~km}^{2}\right)$. The northern part is very urbanized and limited by the Seine River, whereas the southern part is less populated with the presence of several forests. The Hauts-de-Seine climate is very close to the rest of the Paris Basin with mild Winters, frequent rainfalls in Autumn, mild Spring and high Summer temperatures with possible occurrence of intense rainfalls. The average annual rainfall over the county is about $700 \mathrm{~mm}$, whereas the decennial hourly rainfall is about $35 \mathrm{~mm}$.

Because of the rapid growth of urbanization during the 90's and the difficulty to build new management infrastructures due to its density, the stormwater network is very sensitive to intense precipitation which can cause local flooding. Since the beginning of the 2000's, the local authority in charge of water management (Water Direction of the Haut-de-Seine county) tries to mitigate these problems by the use of Sustainable Urban Drainage System (SUDS). In this context, the Hauts-de-Seine county has set up a grant policy to promote regulated flat roofs. An extension of $40 \mathrm{~mm}$ with small diameter holes located on the top of the downspouts is used to regulate the roof flow rate. This regulated system is not always accepted by green 
1 roof professionals, because of the unknown impacts on the vegetation structure. The Water

2 Direction is also interested in studying the impacts of existing and future green roofs on urban runoff in order to refine their approach in urban hydrology.

As a consequence, two urban watersheds have been chosen, in coordination with the Water Direction, to study the possible impact of green roofs at the basin scale. They are located in Châtillon and Boulogne-Billancourt. Their combined sewer networks are both affected by urban runoff problems during storm events.

Châtillon is a basin of $2.4 \mathrm{~km}^{2}$ characterized by quite steep topography with an average slope of $3.5 \%$. The upstream part of the basin is essentially covered by individual housing, whereas the downstream part is covered by collective housing and economical activities. Local floodings often occur along the Boulevard de Vanves (see Figure 1), a main road crossing the city center. The pipe along the Boulevard up to the outlet is not large or/and steep enough to route the runoff during intense rainfall. It seems that flooding occurs (almost every year) when the discharge exceeds the limit value of $5 \mathrm{~m}^{3} / \mathrm{s}$ at the outlet.

Boulogne-Billancourt $\left(5.5 \mathrm{~km}^{2}\right)$ is a densely urbanized basin near Paris with an average slope of $0.5 \%$, and mainly occupied by collective housing. The southern periphery is more diversified with offices, parks, and industrial wasteland. The basin is often affected by CSOs to the Seine River, which surround a large part of the city (see Figure 1). The frequency of these CSOs is approximately monthly with significant volumes that could be discharged during intense storm. During the last significant event, in July 2010, the total monthly overflowed volume reached $150,000 \mathrm{~m}^{3}$.

In order to assess the hydrological impact of green roofs on both basins, several geographical, technical and hydrometeorological data have been obtained. They are useful to: (i) estimate their green roofing potential, and (ii) model their hydrological behaviour. These 
data comprise:

- Land use information: The database, called MOS (for "Mode d'Occupation des Sols" in French, see IAU-IDF, 2008), classifies the land surface into 81 main land use categories.

- Topological information: This database called BD TOPO® data (IGN, 2011) includes surface information on the spatial distribution of buildings, roads, rail or hydrographic network.

- Basin information: basin contours, disaggregation into sub-basins and sewage network data (including the layout and the geometrical properties of pipes and sewage infrastructures, operating rules and dry weather flow data) were provided by the Water Direction of the Hauts-de-Seine county.

- Precipitation and potential evapotranspiration (ETP) data: A continuous precipitation database from a rain gauge located close to both basins was provided by the Water Direction. A continuous ETP database was provided by Meteo-France. They cover a full time period from 1993 to 2011 (excepted 1996) with a time resolution of 5 minutes.

- Discharge data: No automatic continuous stream gauge station is installed in the Châtillon basin, but a monitoring programme was conducted from April to June in 2009 to evaluate the discharge at the outlet. On the other hand, Boulogne-Billancourt basin outlet is instrumented by a stream gauge (characterized by a 5-minute resolution). Flow measurements were provided on the 2010-11 time period.

\section{Hydrological modelling framework}

In order to test the possibility to mitigate the basin vulnerability and to reduce both flooding 
and CSO risks, the impact of virtual green roofs has been assessed. Firstly, the studied basins have been modelled to simulate their current response to rainfall. Secondly, this model was used with a specific module representing green roof hydrological behaviour previously developed and presented in details in Versini et al. (2014). Finally, the potential for green roofing has been defined at the sub-basin scale by combining several geographic data, this potential is used to compute realistic green roofing scenarios.

\subsection{Rainfall-runoff simulations with SWMM}

Both basins have been represented in the Storm Water Management Model (SWMM, see Rossman, 2004) which is a dynamic rainfall-runoff model especially developed for urban/suburban areas by the United States Environmental Protection Agency (EPA). Both sewer networks including junction nodes, conduits, and specific infrastructures (weir, orifice, storage unit ...), have been designed to simulate and estimate the hydrological behaviour of the Châtillon and Boulogne-Billancourt basins. As SWMM is a semi-distributed model, each basin is divided into several sub-basins onto which the water balance is computed (see Figure 2).

In order to reproduce correctly the hydrological behaviour of both studied basins, SWMM representations have been tested on past events and compared to discharge observations. In the Châtillon basin, where no continuous measurements were available, simulations have been performed on 3 rainfall events (total precipitation higher than $12 \mathrm{~mm}$ ). SWMM simulations appeared to be excellent with a good representation of the peak discharges and a significant Nash-Sutcliffe efficiency (Nash and Sutcliffe, 1970) higher than 0.85. The Boulogne-Billancourt basin simulation was evaluated by a Nash-Sutcliffe efficiency equal to 0.65 over the 2010-2011 time period. As every peak discharge was well represented, it seems the efficiency deteriorated because of the poor representation of dry weather inflows. 
1 Some examples of these simulations are illustrated in Figure 2: one of the 3 rainfall events available on the Châtillon basin and the most severe rainfall event for the BoulogneBillancourt basin. These results show that observations and simulations match very well at the event scale.

\subsection{Presentation of the green roof module}

The SWMM module called "Bio-retention Cell" has been significantly modified to simulate the hydrological response of green roofs. This module is based on the model developed by Berthier et al. $(2010,2011)$ representing each layer of green roof infrastructure (vegetation, substrate and drainage) by 3 different reservoirs. The model parameters have been adjusted by using an experimental green roof setup on the site of CETE Ile-de-France in Trappes $(45 \mathrm{~km}$ South-West from Paris, France).

The whole area of the CETE roof (about $400 \mathrm{~m}^{2}$ ) was split into several compartments $\left(35 \mathrm{~m}^{2}\right)$ differentiated by their type of green roof (type of vegetation, substrate thickness, type of drainage). A detailed presentation of the experimental site is available in Gromaire et al. (2012). The reservoir model has been especially adjusted (for more details, please refer to Versini et al., 2014), for two configurations comprising an extensive vegetation (sedum), a substrate layer and a drainage layer with expanded polystyrene. Both green roof configurations differ in the substrate depth. For the first one, called SE3Y, the thickness is $3 \mathrm{~cm}$ and for the second one, called SE15Y the thickness is $15 \mathrm{~cm}$.

Meteorological and hydrological data (time step of 3 minutes) compiled from June 2011 to July 2012 have been used to calibrate and validate the model. Satisfactory results were obtained for both configurations, especially for the largest rainfall events. Dynamics of runoff were well reproduced with a Nash-Sutcliffe efficiency close to 0.8 at the storm event scale. Moreover, the total water balance was correctly respected with an error in volumes close to 
$110 \%$ (this underestimation seems to be related with the overestimation of evapotranspiration

2 but do not affect the representation of peak discharges). Some of these performances are

3 illustrated in Figure 3, where the cumulative runoff and a couple of storm events (one in

winter and one in summer) are depicted for SE15Y configuration.

Finally, as the green roof module and SWMM basin configurations provide very satisfactory results, they have been combined for testing the green roof impact on flooding and CSO issues. The green roof module is applied at the sub-basin scale on an area representing the total green surface (not at the building scale).

\subsection{Evaluation of a green roofing potential}

\subsubsection{Definition}

The potential of green roofing is estimated by combining land use (IAU-IDF, 2008) and building data contained in BD TOPO ${ }^{\circledR}($ IGN, 2011). The hypothesis has been made that buildings belonging to some specific classes (collective housing, industrial and economic activities, public buildings) could be easily implemented with green roofs (assuming that these roofs are mainly flat). In each class, the roof areas have been deduced by identifying the building areas from the second database (BD TOPO $\left.{ }^{\circledR}\right)$.

Finally, the potential of green roofing is defined as the percentage of the total subbasin area that could be covered by such technology. It is a high estimation of the real green roofing potential since it assumes that all selected buildings roofs: (i) are flat and without any other equipment (sky-domes, technical materials), (ii) can effectively and technically be "greenable". Note that the assumption on flat roofs is consistent with both cities urbanism. These potentials also represent a maximum value. Green roofing scenarios will be deduced by selecting a part of this potential. 
2 The methodology has been applied to both case studies and the results are illustrated in Figure

\subsubsection{Spatial distribution on the studied basins}

1. The potential of green roofing appears to vary significantly from one sub-basin to another. An average green roofing potential value of $20 \%$ of the total catchment is calculated for Châtillon basin. The downstream part of the basin (where individual housing are located) is characterized by a low potential, close to $10 \%$, whereas almost all the sub-basins located upstream from the Boulevard de Vanves have a higher potential, locally reaching more than $50 \%$. The green roof potential is higher and more spatially homogeneous on the BoulogneBillancourt basin. The average green roofing value is $29.1 \%$ and ranges from $5 \%$ in the south part (which is currently a former industrial site) to $45 \%$ in the central part (where collective housing and economical activities are concentrated).

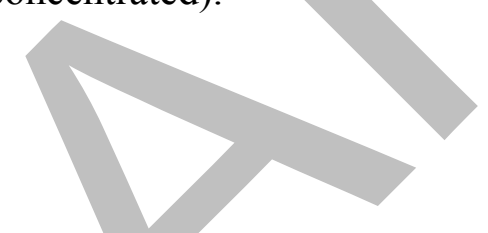

\section{Study of Green roof impacts}

\subsection{Methodology}

For both studied basins, different scenarios of green roofing have been provided. They are based on the potential of green roofing computed at the sub-basin scale. These scenarios correspond to the covering of $12.5,25,50$ and $100 \%$ of the previously defined green roofing surface by SE3Y and SE15Y configurations. In SWMM, these green roof surfaces have been subtracted from the impervious areas at the sub-basin scale. The green roof module, previously integrated into SWMM, is used to compute runoff for these particular surfaces. Acting in parallel, discharges computed for every contributing surface are added to provide the total sub-basin response.

Precipitation time series on the 1993-2011 time period have been used to simulate the hydrological behaviour of both basins. Such a long period seems sufficient to capture current 
1 events (peak discharge and monthly overflowed volumes) characterized by a return period

2 lower than 10 years. For both basins, 35 storm events for which sewage problems occurred

3 have been analysed to see the possible impact of green roofs at the event scale. The

4 accumulated rainfalls of these events reached 2.6 to $120 \mathrm{~mm}$ (representing an intensity of 2.5

5 to $41 \mathrm{~mm}$ per hour). Regarding the Intensity-Duration-Frequency (IDF) curves, these events

6 are characterized by some return periods ranging from one month to more than 10 years.

7 Before being used, potential evapotranspiration data have been adjusted by using a coefficient

8 calibrated on the experimental site ( 0.5 in winter and 0.7 in summer for SE15Y for example).

Since both studied basins are exposed to a different issue (flooding and CSO), a specific framework has been defined for each case:

- In the Châtillon basin, which is affected by flooding, the peak discharge flowing through the Boulevard de Vanves has been studied and the return period of annual maximum peak discharge has been particularly calculated. The corresponding midbasin (100 ha) is located downstream of the Boulevard de Vanves.

- For the Boulogne-Billancourt basin, which is affected by CSOs, the volumes overflowing into the Seine River have been studied. The analysed value represents the cumulative overflowed volumes to the receiving environment by the different outlets located around the basin (see Figure 1). As these overflows are very usual, the frequency of the monthly overflowed volume has also been calculated.

The resulting hydrological indicators (simulated peak discharges and overflowed volumes) have been computed for the different green roofing scenarios. Then, they have been compared to the values corresponding to the current situation (without green roof). 
2 Simulation results are synthesised in the following sub-sections. First the general impact and

\subsection{Presentation of the results} scale effect are studied, then the results concerning flooding and combined sewage overflow issues are presented.

\subsubsection{General impact on urban runoff and scale effect}

Results are synthesized in Table 1. Firstly, it has to be noticed that there is no significant difference between the results obtained for SE3Y and SE15Y green roof configurations. The influence of the total covered area appears to be more important than the substrate thickness. The decrease in total runoff volume, peak discharge or overflowed volume due to green roofing obviously appears to be higher for SE15Y, but this difference is stronger for the lowest rainfall events. In fact, retention depends on the amount of moisture lost by evapotranspiration prior to rainfall intensity. This has also been noticed on the experimental green roof setup in Trappes and in previous studies (Voyde et al., 2010, Versini et al., 2014). For this reason and for a question of clarity, only the results provided for SE15Y are represented in the next figures $(3,4,5$, and 6$)$.

The total annual runoff volume drained by each basin has been computed for every year of the studied time period (not represented here). The impact of green roofs appears to be quite marginal at the annual scale. The runoff volume reduction ranges from $0.1 \%$ (for a coverage of $12.5 \%$ of the green roofing potential) to $6 \%$ (for a coverage of $100 \%$ ) on the Châtillon basin. As the average green roofing potential is $20 \%$, these values are quite low. The influence of green roofs is more significant for the Boulogne-Billancourt basin: here the runoff volume reduction ranges from $0.1 \%$ to $14 \%$ depending on the green roofing scenarios and the considered year. The reduction seems to be proportional to the green roofing potential 
covered.

No scale effect is visible when comparing the results for the three studied scales (subbasin, mid-basin, basin). The results are clearly related to the green roofing potential and not on the size of the three entities (see Figure 5). A low potential has to be compensated by a higher percentage of covering in the same proportion. As both basin and mid-basin are characterized by a similarly low potential (between $15 \%$ and $25 \%$ ), the impact of green roofing represents a decrease in approximately $35 \%$ for peak flow and $15 \%$ for runoff volume in the best case (scenario with $100 \% \mathrm{SE} 15 \mathrm{Y}$ ). A significant modification of discharge appears when at least $50 \%$ of the potential is covered. In this case, a peak discharge decrease of $15 \%$ is observed. At the sub-basin scale, characterized by a green roofing potential higher than $50 \%$, these modifications are more important, with a maximum decrease of $60 \%$ for peak flow and $45 \%$ for runoff volume (for the $100 \%$ SE15Y scenario). It should be noted that a low covering of the potential $(25 \%)$ appears to be enough to reduce significantly the peak discharge (of about 15\%).

\subsubsection{Impacts on flooding (Châtillon basin)}

The simulated peak discharges appear to be influenced by the implementation of green roofs when large roof surfaces are covered. The statistical distribution of annual peak discharge represented in Figure 4 shows that $50 \%$ of the green roofing potential (representing $10 \%$ of the total basin area and $25 \%$ of the total impervious area) has to be covered to reduce the peak discharge by $15 \%$, whatever the considered return period. When $100 \%$ of the potential is covered, the decrease in peak discharge can reach up to 35\%. The performance of green roof is also to be reduced for the larger events. For these cases, the substrate is at field capacity and cannot infiltrate anymore. The effect of the finite retention capacity was already mentioned in previous studies (Carson et al., 2013; Fassman-Beck et al., 2013). Moreover, a seasonal effect 
1 can be seen. For the reason mentioned above (the substrate is at field capacity), green roof has

2 less impact in winter than in summer.

The simulated discharge time series for the basin outlet is also represented for the particular storm event of June 2009, for which the value was over the threshold of $5 \mathrm{~m}^{3} / \mathrm{s}$ (Figure 4). As for the statistical distribution, a significant decrease in peak discharge (about $20 \%$ ) only occurs when almost $50 \%$ of the potential is covered (a decrease in $35 \%$ is noticed for $100 \%$ of the potential). Nevertheless, a potential coverage $(12 \%$ or $25 \%)$ is enough to reduce the peak discharge to below $5 \mathrm{~m}^{3} / \mathrm{s}$ and theoretically avoid flooding (see also Figure 4).

\subsubsection{Impact on Combined Sewage Overflow (Boulogne-Billancourt basin)}

Monthly volumes of CSO have been computed for the complete time series. Their statistical distribution is illustrated in Figure 6. Whatever the green roofing scenario, the distribution is modified from the normal values to the rarest ones. The overflowed volume is completely avoided for the more common events (return period lower than 2 months) when $100 \%$ of the potential is covered. For less frequent events ( 2 months $<\mathrm{T}<1$ year), CSO volumes can be divided by two in the same circumstances. Intermediate scenarios $(50 \%$ of the potential covered) provide a $30 \%$ reduction of these volumes. Note that the reduction in CSO volume seems to be higher for the lowest frequencies.

Regarding the results for the 35 studied events (Figure 6), the covering of only $12.5 \%$ of the potential seems to produce only a low impact in terms of overflowed volume reduction (an average decrease about $7.6 \%$ ). The covering of 50\% generates an average decrease about $35 \%$, whereas the covering of $100 \%$ induces a significant decrease reaching $60 \%$ of the CSO 
volume.

\section{Discussion}

These encouraging results are based on a number of implicit hypotheses and

5 limitations that are worth discussing:

Optimistic estimation of the green roofing potential: as described in this paper, the methodology implemented to estimate the potential of green roofing at the sub-basin scale probably overestimates the real potential. It is assumed that all buildings belonging to the selected land use categories can effectively be covered by green roof, meaning that they have flat roofs, without impeding micro-structure and for which the implementation of green roof is technically possible and not already implemented. Although the green roofing of slightly sloping roofs may be possible, scenarios based on the covering of $100 \%$ of the defined potential are clearly unrealistic. Nevertheless, they illustrate the potential of such structures and encourage the implementation of green roofs for future rehabilitation and developing projects. The results obtained for intermediate scenarios (covering of 25 to $50 \%$ of the potential) demonstrate the covering of a significant -but more realistic- part of roof surfaces can provide satisfactory improvement in terms of urban runoff management. Moreover, this study has been conducted by using traditional green roofs. The use of regulated ones - as encouraged by the Hauts-de-Seine County - could still improve their performance by storing more water in the drainage roof structure.

- Short time period for the calibration of the hydrological model: hydrological model parameters have been adjusted using one year of observed discharge. Nevertheless, from June 2011 to July 2012, no severe events were observed. That means the model 
has been developed to reproduce common events (characterized by a return period lower than 1 year), and we assume it is able to represent correctly rarer events characterized by more intense precipitation. For this reason, the observation of experimental green roofs has to continue in order to capture some more significant storm events. These additional data will be used to improve and/or validate the model in the future. However, the use of current data allows the conclusion that the implementation of green roofs can be useful to limit the consequences of common storm events on sewage network.

- These results have been computed for two particular urban basins belonging to the Hauts-de-Seine county. For this reason, the figures obtained in terms of flooding and CSO reduction cannot be generalized and transferred to other locations. Indeed, they depend on the basin configuration, especially in terms of green roofing potential but also on the geometry. In different cases, concomitance problems (when a sub-basin response slowed by green roof coincides now with the response of another sub-basin and finally produce an higher discharge) could occur.

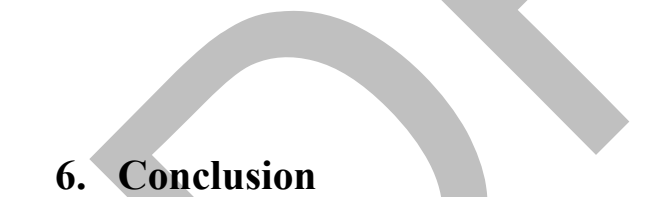

6. Conclusion

A methodology to study the impact of green roof at the catchment scale has been developed. It includes the design of green roofing scenarios based on a land use analysis and a model simulating the hydrological behaviour of these surfaces. Integrated into an urban rainfallrunoff model, this tool has been applied on two urban catchments suffering specific operational issues (flooding and CSO) in the Haut-de-Seine county.
} 
1 sewage overflow. The magnitude of both peak discharge and overflowed volumes decrease

2 depends strongly on the effective green roof covering (which is the product of green roof

3 potential and green roof covering). The covering of $100 \%$ of the identified implementable

4 roof surfaces result in a significant decrease in peak discharge (between 30 and $60 \%$

5 depending on the green roofing potential), runoff volume (between 15 and 45\%) and

6 overflowed volume (more than 60\%). A lower covered area (25 to $50 \%$ of the identified

7 potential), more representative of the reality, is expected to partially reduce the studied

8 problems. It has also appeared that substrate thickness is not really significant regarding the

9 impacts noted at the basin scale.

The definition of generalized recommendation to reduce urban runoff depending on green roof implementation represents a large perspective for future investigations. It is one of the objectives of the TVGEP project supporting this work. Based on this study, the following conclusions can be provided. One hectare of green roof allows the retention of $4500 \mathrm{~m}^{3}$ per year (representing $450 \mathrm{~mm}$ of precipitation). At the basin scale, if $10 \%$ of the basin area is covered by green roof, peak discharge is reduced by $16 \%$ and overflowed volume by $20 \%$. It also seems that green roof is more efficient in reducing the overflowed volumes than flooding. sewage network overflows. Combined with other stormwater source controls and/or retention infrastructures, green roofs could participate to significantly reduce the quantity of water flowing into the sewage network during storm events. In addition to thermal and environmental benefits, green roofs can be valuable from an urban water management point of view. This kind of study could be used by policy makers and water management authorities to promote the implementation of green roofs in the future. 


\section{AKNOWLEDGMENTS}

This work has been supported by the French C2D2 framework programme through the TVGEP project. The authors would like to thank the Water Direction of the Haut-de-Seine county, especially Christian Roux and Christophe Lehoucq, for providing geographical and hydrometeorological data and expertise.

\section{LIST OF REFERENCES}

Bengtsson, L. 2005. Peak flows from thin sedum-moss roof. Nordic Hydrol. 36 (3), 269-280.

Berthier, E., de Gouvello, B. and Archambault, F. 2010. Bilan hydrique des toitures végétalisées : vers de meilleures compréhension et modélisation. Techniques sciences méthodes, 6: 39-46.

Berthier, E., Ramier, D., and de Gouvello, B. 2011. Simulation of Green Roof Hydrological Behavior with a Reservoir Model. In: ICUD, $11-16^{\text {th }}$ September 2011, Porto Alegre, Brésil.

Campisano A., Creaco E., and Modica C. 2011. A simplified approach for the design of infiltration trenches. Water Science and Technology, 64(6), 1362-1367

Carson, T.B., Marasco, D.E., Culligan, P.J. and McGillis, W.R. 2013. Hydrological performance of extensive green roofs in New York City: observations and multi-year modeling of three full-scale systems. Environmental Research Letters, 8(2): 24-36.

Carter, T. and Jackson C. R. 2007. Vegetated roofs for stormwater management at multiple spatial scales. Landscape and urban planning, 80, 84-94.

Chouli, E. 2006. La gestion des eaux pluviales urbaines en Europe: analyse des conditions de développement des techniques alternatives. Thesis (Ph.D). Cereve, Ecole Nationale des Ponts et Chaussées, Paris.

Delleur, J., 2003. The evolution of urban hydrology: past, present, and future. Journal of Hydraulic Engineering, 129, 563-573.

Egodawatta, P., Thomas, E., Goonetilleke, A. 2009. Understanding the physical processes of pollutant build-up and wash-off on roof surfaces. Science of the Total Environment, 407(6), 1834-1841.

Fassman-Beck, E., Voyde, E., Simcock, R. and Hong, Y.S. 2013. 4 Living roofs in 3 locations: Does configuration affect runoff mitigation? Journal of Hydrology, 490: 11-20.

Ferguson, B.K. 1998. Introduction to Stormwater: Concept, Purpose and Design. Wiley, New York.

Gregoire, B.G. and Clausen, J.C. 2011. Effect of a modular extensive green roof on stormwater runoff and water quality. Ecological Engineering, 37, 963-969

Gromaire, M. - C., Robert-Sainte, P., Bressy, A., Saad, M., de Gouvello, B. and Chebbo G. 2011. $\mathrm{Zn}$ and $\mathrm{Pb}$ emissions from roofing materials - Modelling and mass balance attempt at the scale of a small urban catchment, Water Science and Technology. 63: 2590-2597.

Gromaire, M. - C., Ramier, D., Seidl, M., Berthier, E., Saad, M., and de Gouvello, B. 2012. Incidence of extensive green roof structures on the quantity and the quality of runoff waters. In NOVATECH, 23-27 $7^{\text {th }}$ June 2013, Lyon, France. Submitted 
Hilten, R.N., Lawrence , T.M., Tollner, E.W. 2008. Modeling stormwater runoff from green roofs with HYDRUS-1D. Journal of Hydrology, 358, 288-293.

IAU-IDF 2008. Base de connaissance sur le Mode d'Occupation du Sol (MOS). Institut d'Aménagement et d'Urbanisme de l'Ile de France: http://www.iau-idf.fr/

IGN 2011. BD TOPO ${ }^{\circledR}$ Descriptif de contenu. Institut Géographique National: http://professionnels.ign.fr/

Jarrett, A., Hunt, W. and Berghage, R.. 2006. Annual and individual storm green roof stormwater response models. In: ASABE Annual International Meeting. Sponsored by ASABE, Oregon Convention Center, Portland, Oregon, 9-12 ${ }^{\text {th }}$ July.

Lassalle, F.. 2012. Panorama technique, historique et géographique. In : Quelle place pour les toitures végétalisées dans la ville de demain, $20^{\text {th }}$ November 2012, Paris (France).

Mentens, J., Raes, D. and Hermy, M. 2006. Green roofs as a tool for solving the rainwater runoff problem in the urbanized $21^{\text {st }}$ century. Landscape and urban planning, 77, 217-226.

Nash, J.E. and Sutcliffe, J.V. 1970. River flow forecasting through conceptual models part I A discussion of principles. Journal of Hydrology, 10(3): 282-290.

Palla, A., Lanza, L.G. and La Barbera, P. 2008a. A green roof experimental site in the Mediterranean climate, In $11^{\text {th }}$ International Conference on Urban Drainage, Edinburgh (Scotland).

Palla, A., Berreta., C, Lanza, L.G.and La Barbera, P. 2008b. Modelling storm water control operated green roofs at the urban catchment scale. In $11^{\text {th }}$ International Conference on Urban Drainage, Edinburgh, (Scotland).

Palla, A., Gnecco I., Lanza L.G. 2009. Unsaturated 2D modelling of subsurface water flow in the coarse-grained porous matrix of a green roof. Journal of Hydrology, 379, 193-204

Petrucci, G., Rioust, E., Deroubaix, J.-F. and Tassin B. 2012. Do stormwater source control policies deliver the right hydrologic outcomes? Journal of Hydrology, In press. http://dx.doi.org/10.1016/j.jhydrol.2012.06.018

Rossman, L.A. 2004. Storm water management model User's manual version 5.0. Cincinnati, OH: U.S. EPA. Water Supply and Water Resources Division, National Risk Management Research Laboratory.

Stovin, V., Vesuviano, G. and Kasmin, H. 2012. The hydrological performance of a green roof test bed under UK climatic conditions. Journal of Hydrology, 414-415: 148-161.

Urbonas, B.R. and Jones, J.E. 2001. Summary of emergent urban stormwater themes. In: Urbonas, B.R. (Ed.), Linking Stormwater BMP Designs and Performance to Receiving Water Impact Mitigation, ASCE.

VanWoert, N. D., Bradley Rowe, D., Andresen, J.A., Rugh, C.L., Fernandez, R.T., and Xiao L. 2005. Green Roof Stormwater Retention: Effects of Roof Surface, Slope, and Media Depth. Journal of Environnemtal Quality, 34:1036-1044

Versini, P.-A, Ramier, D., Berthier, E. and de Gouvello, B. 2014. Assessment of the hydrological impacts of green roof: from roof scale to basin scale. Journal of hydrology, under review

Villarreal, E.L. and Bengtsson, L., 2005. Response of a Sedum green-roof to individual rain events. Ecological Engineering, 25(1): 1-7

Voyde, E., Fassman, E. and Simcock, R. 2010. Hydrology of an extensive living roof under sub-tropical climate conditions in Auckland, New Zealand. Journal of Hydrology, 394(34): $384-395$

White, R. 2002. Building the Ecological City. Woodhead Publication, Cambridge. 


\section{Table}

2

3 Table1. At the annual scale, runoff volume reduction $(\mathrm{min} / \mathrm{mean} / \mathrm{max})$ is computed for every 4 green roofing scenarios on both studied basins ( $\Delta$ Vtot expressed in $\%$ ). At the event scale, 5 peak discharge reduction $(\Delta \mathrm{Qp})$ is indicated for Châtillon and overflowed volume reduction $6(\Delta \mathrm{Vcso})$ is indicated for Boulogne-Billancourt basin.

7 8 

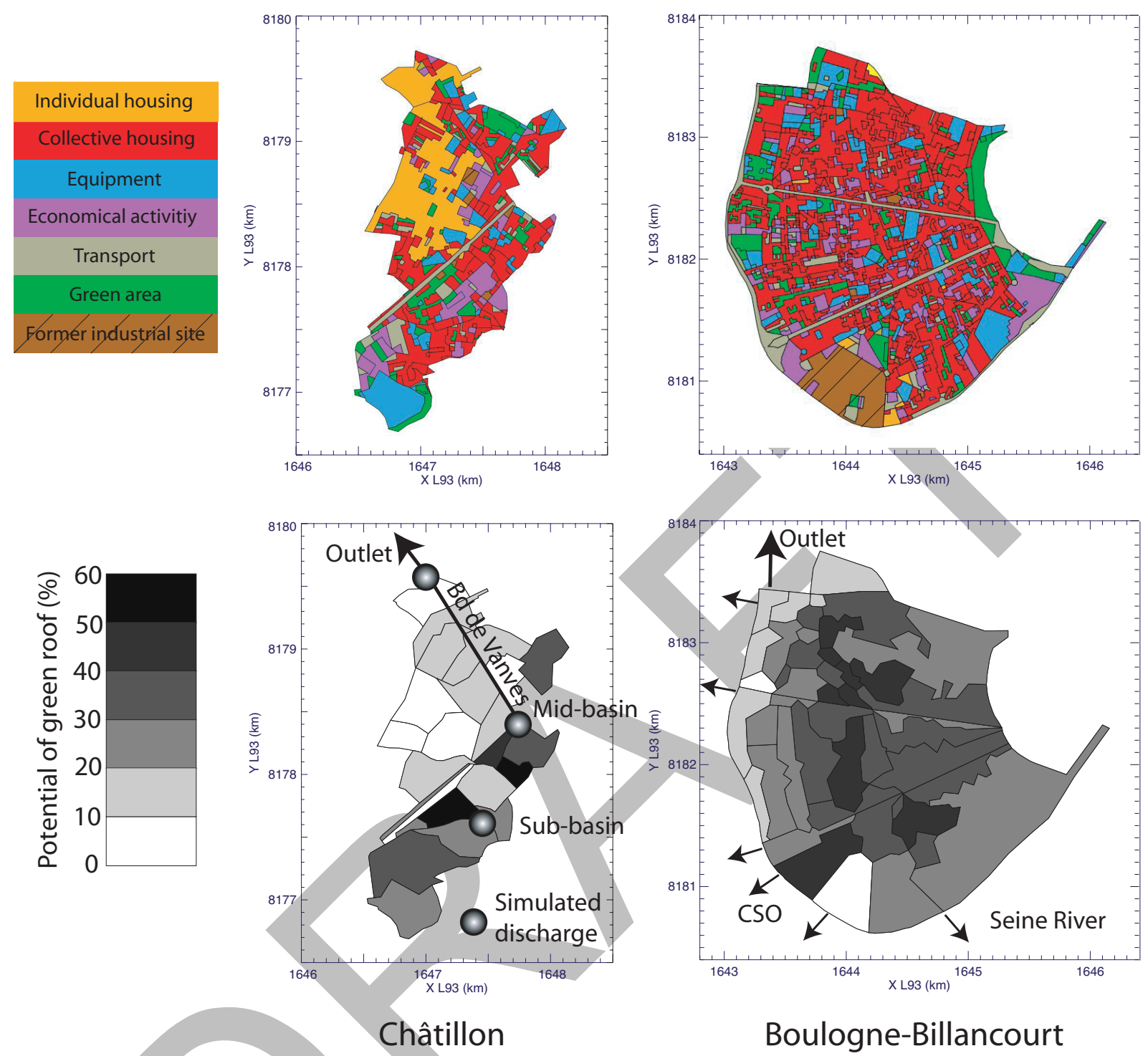

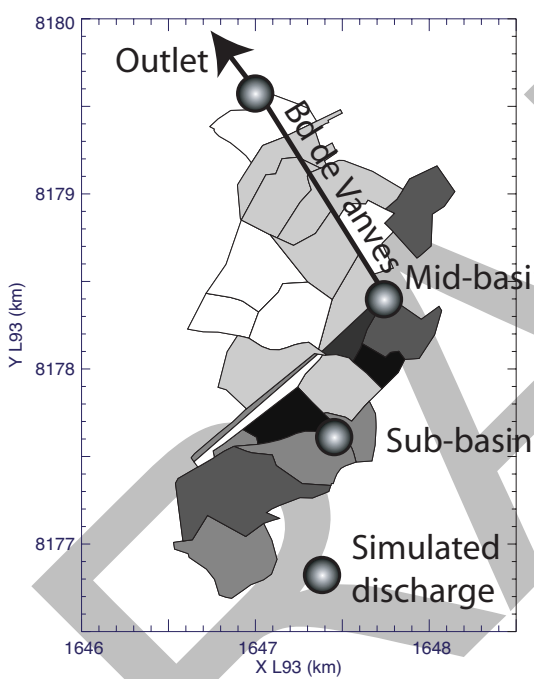

Châtillon

Boulogne-Billancourt

3 Figure 1. Spatial distribution of land use (top) using MOS with 11 categories (IAU-IDF,

4 2008) and green roofing potential (bottom) for Châtillon (left) and Boulogne-Billancourt

5 (right) basins. The locations of management issues (flooding and CSO) are also represented. 

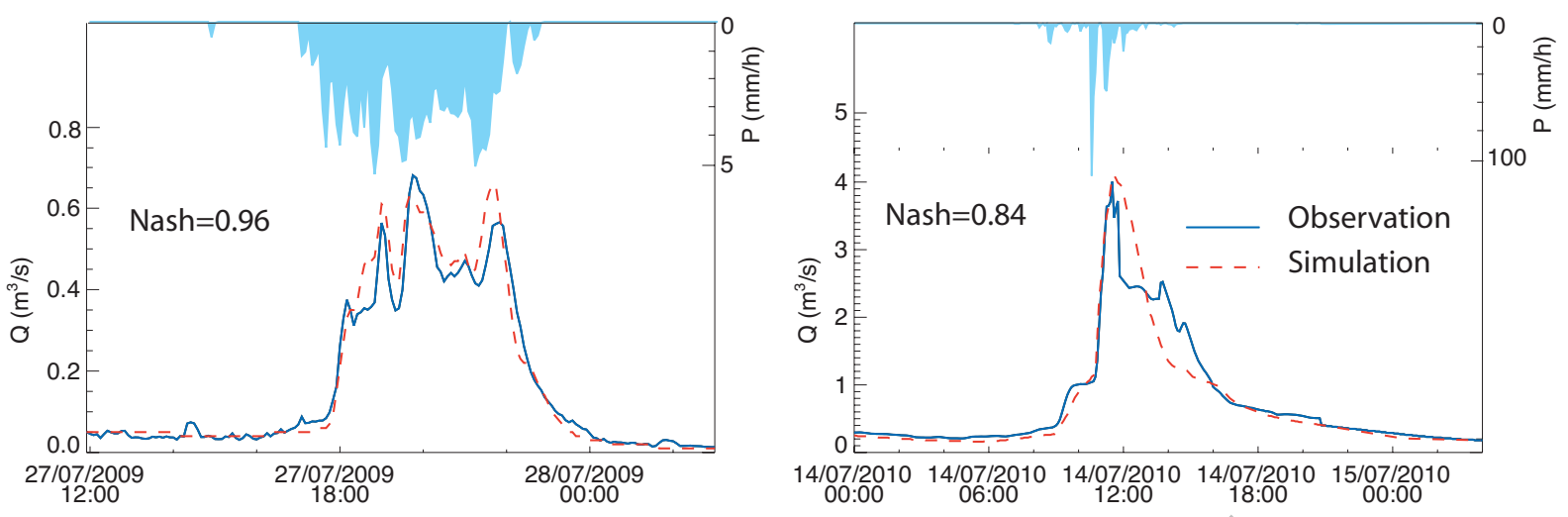

2 Figure 2. Comparison between observations and SWMM simulations for Châtillon (left) and

3 Boulogne-Billancourt (right)
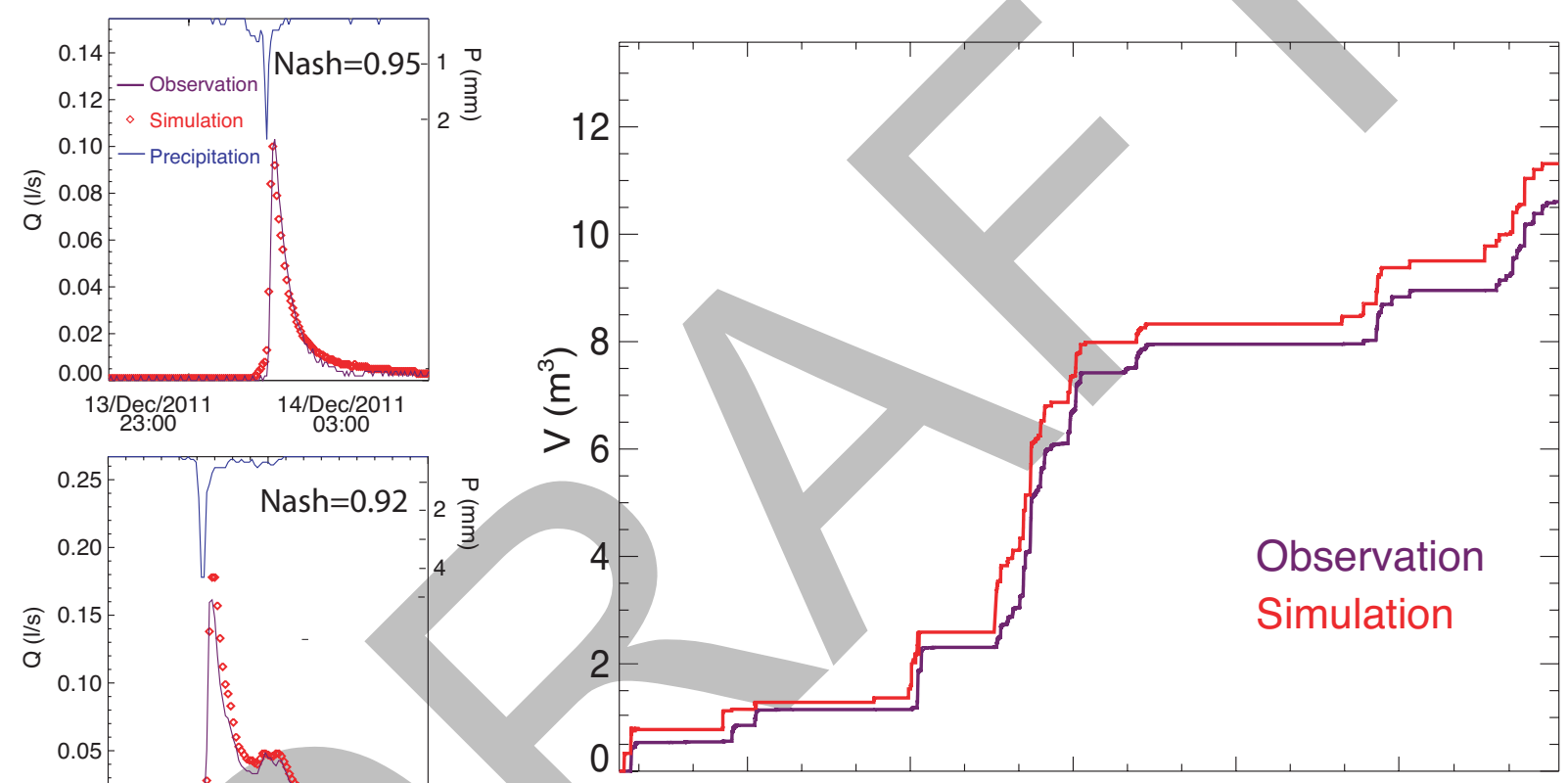

Sep/2011 Nov/2011 Jan/2012 Mar/2012 May/2012

4

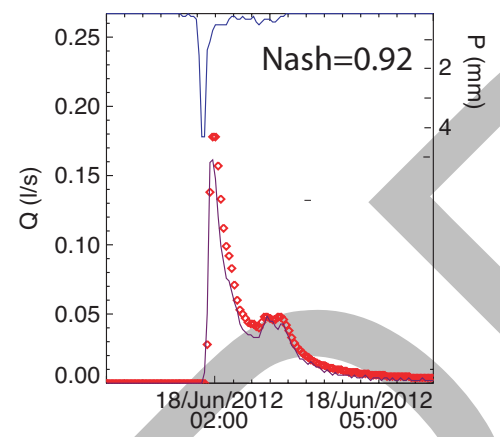

Observation

Simulation

5 Figure 3. Comparison between observed and simulated discharges for the SE15Y

6 configuration. Two storm events are depicted on the left (one in winter and one in summer).

7 The cumulative runoff is represented on the right. 

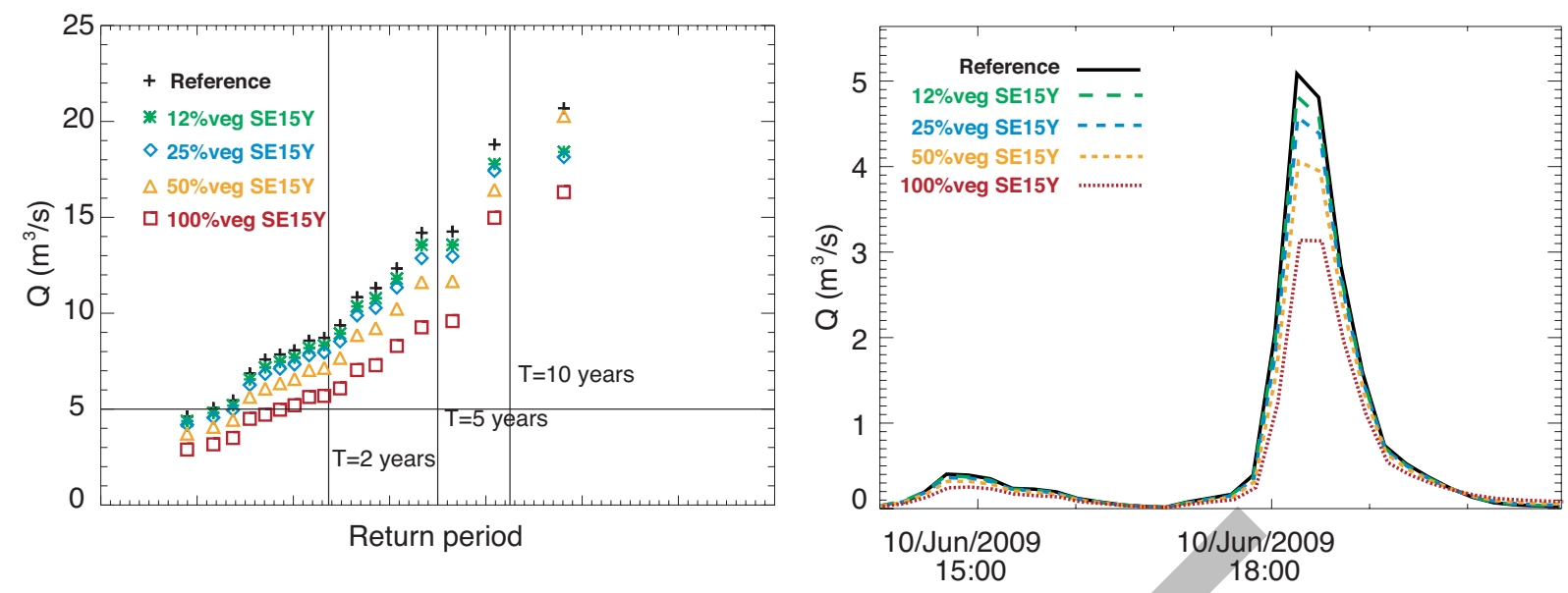

2 Figure 4. Results of the SWMM simulations for Châtillon basin by using the different green

3 roofing scenarios: the statistical distribution of annual peak discharge is represented on the

4 left $(5 \mathrm{~m} 3 / \mathrm{s}$ threshold is indicated $)$ and the storm event of June 2009 is represented on the 5 right.

6

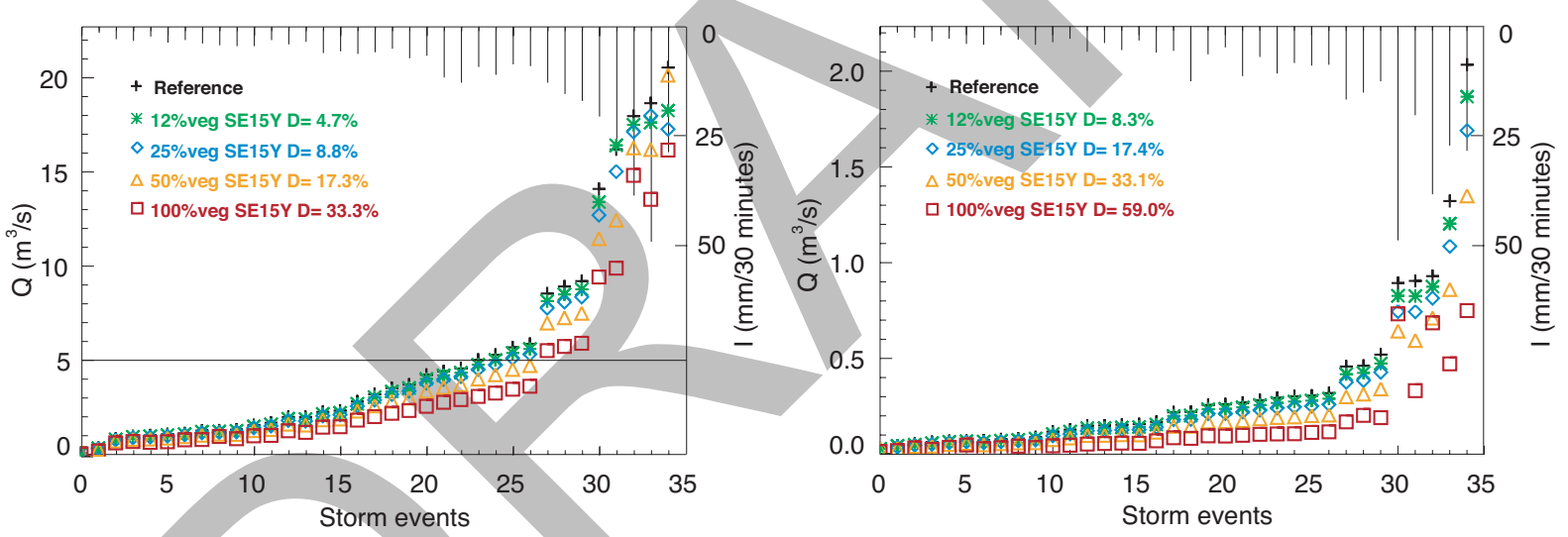

8 Figure 5. Results of the SWMM simulations for Châtillon basin by using the different green

9 roofing scenarios: modifications of the peak discharge for each storm event are represented

10 for the total basin on the left and for the sub-basin on the right. Bars at the top represent

11 rainfall intensity. 

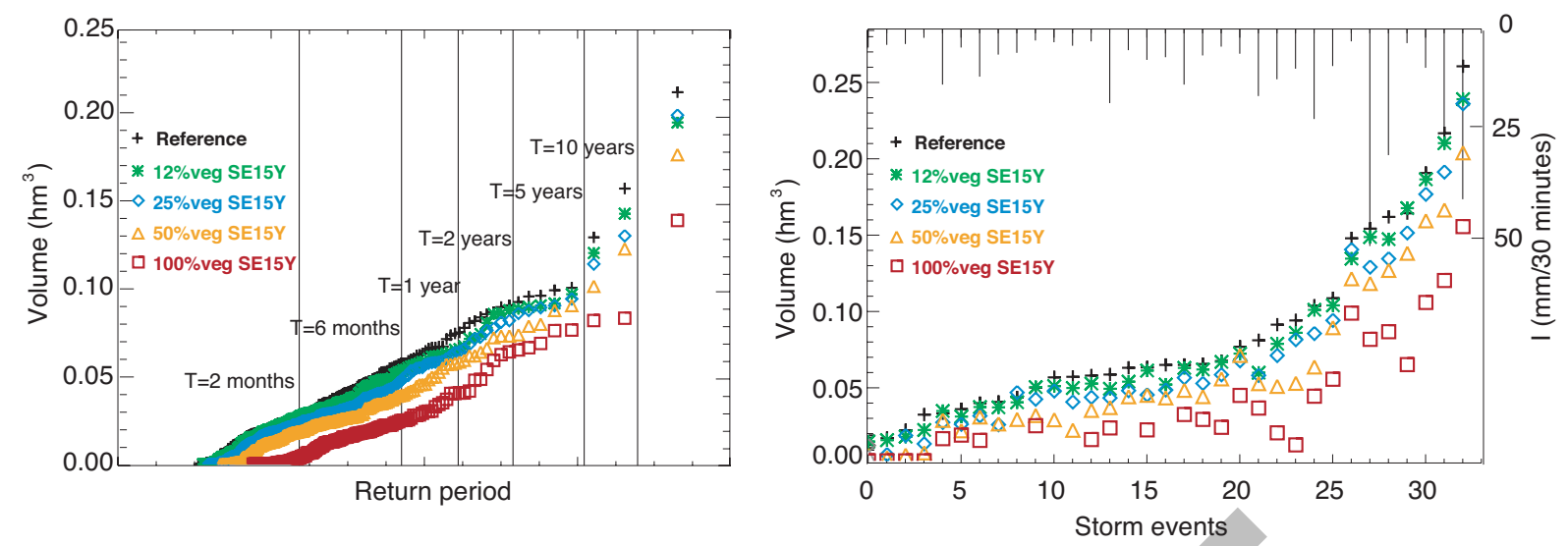

2 Figure 6. Results of the SWMM simulations for Boulogne-Billancourt basin by using the

3 different green roofing scenarios: the statistical distribution of overflowed volume is

4 represented on the left and modifications of peak discharge by storm event are represented on 5 the right (Bar at the top represents rain intensity). 